\title{
Orchidaceae of the Grumari restinga: floristic and similarity among restingas in Rio de Janeiro state, Brazil
}

\author{
Marina Muniz Moreira ${ }^{1,2}$, Felipe Fajardo Villela Antolin Barberena ${ }^{2}$ and Rosana Conrado Lopes ${ }^{1,3}$
}

Received: May 10, 2013. Accepted: January 9, 2014

\begin{abstract}
Orchidaceae is one of the largest and most diverse plant families in the world. The number of floristic studies of this family in Rio de Janeiro state, Brazil, has increased significantly in recent years. However, only a few such studies have been conducted in areas of restinga vegetation and none of those have examined the similarity, in terms of orchid diversity, among such areas. The present study sought to improve our knowledge of the Orchidaceae diversity occurring in Grumari restinga, as well to compare the diversity of orchids among Grumari and other restinga areas using cluster analysis. We found 15 genera and 19 species. Cluster analysis demonstrated that restingas located on islands are considerably different from those on the mainland, and no relationship was observed between floristic similarity and geographical proximity. As such, the present study shows that each area of restinga hosts different Orchidaceae species, demonstrating the importance of preserving this threatened ecosystem and this plant group.
\end{abstract}

Key words: Conservation, orchids, taxonomy

\section{Introduction}

Orchidaceae is one of the largest and most diverse plant families in the world, with approximately 810 genera and 24.000 species (Chase et al. 2003). The family has a worldwide distribution, ranging from Sweden and Alaska in the north to Tierra del Fuego in the south, with the neotropics being its center of diversity (Dressler 1981). There are 240 genera and 2.440 species known from Brazil, of which 207 genera and 802 species can be found in Rio de Janeiro state (Barros et al. 2013). According to Fraga et al. (2005), Orchidaceae is the third most representative family in the restingas of Rio de Janeiro state, with 64 species. Restingas are an area of sandy coastal plains that occur discontinuously along the Brazilian coast within the Atlantic Forest Biome (Araujo 2000) - which is considered one of the global biodiversity hotspots (Myers et al. 2000).

Floristic studies involving the Orchidaceae family in Rio de Janeiro state have increased significantly in recent years (Miller \& Warren 1996; Saddi et al. 2005; Cunha \& Forzza 2007). However, only two studies have focused on the orchids growing in restingas in that state (Fagnani \& Smith [1998] and Fraga et al. [2005] in the Massambaba and Marambaia restingas, respectively). Few studies have examined orchid diversity among different areas of the state (Azevedo \& Van den Berg 2007; De Abreu et al. 2011) and, even fewer have been carried out in restingas (Fraga \& Peixoto 2004). Moreover, it is important to note that no comparative analysis for the Orchidaceae family have yet been published for the restingas of Rio de Janeiro state.

The present study sought to assess the diversity of orchid species occurring in the Grumari restinga in Rio de Janeiro state, and to compare the diversity of orchids found there with other restinga sites located in the Rio de Janeiro state.

\section{Material and methods}

\section{Study site}

The Grumari restinga is located in the southern region of Rio de Janeiro state (43 $31^{\prime} 00^{\prime \prime}-43^{\circ} 32^{\prime} 30^{\prime \prime} \mathrm{S}$ x $23^{\circ} 02^{\prime}$ $\left.30^{\prime \prime}-23^{\circ} 03^{\prime} 10^{\prime \prime} \mathrm{W}\right)$ (Fig. 1) and occupies approximately 951 ha. The Grumari restinga is one of the smallest restinga fragments remaining in the state (Rocha et al. 2007), and despite being fully inserted into the Grumari Environmental Protection Area (APA Grumari), it has been severely disturbed by the expansion of farms specializing in ornamental plant production. The Grumari restinga has six vegetation formations: halophilous, psammophilous, post-beach, open shrub, closed shrub, and restinga forest. There are also wetlands in the area, which encompasses a

\footnotetext{
${ }^{1}$ Universidade Federal do Rio de Janeiro, Instituto de Biologia, Departamento de Botânica, Rio de Janeiro, RJ, Brazil

${ }^{2}$ Universidade Federal do Rio de Janeiro, Museu Nacional, Programa de Pós- graduação em Ciências Biológicas, Botânica, Rio de Janeiro, RJ, Brazil

${ }^{3}$ Corresponding author: rosana@biologia.ufrj.br
} 


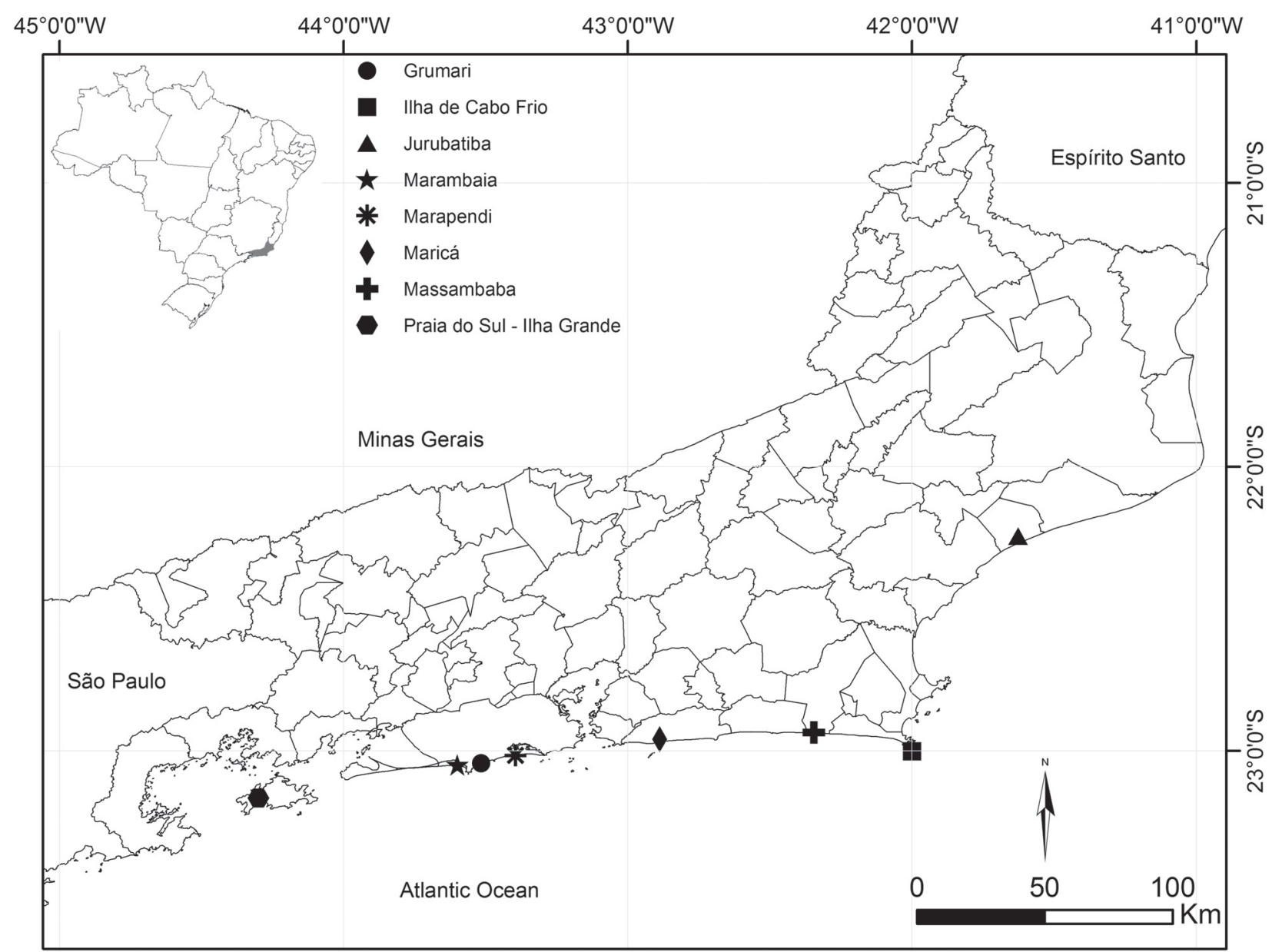

Figure 1. Map showing the locations of the eight areas whose floristic inventories of the Orchidaceae family were used in cluster and ordination analyses.

lagoon (Lagoa Feia) and a river (Rio do Mundo). The local climate is characterized by rains distributed throughout the year, with an average annual rainfall of approximately $1100 \mathrm{~mm}$. The average precipitation for 2009 and 2010 was $1401.6 \mathrm{~mm}$, with a maximum in December $(237.3 \mathrm{~mm})$ and minimum in August (34.5 mm). The average annual temperature is $23.6^{\circ} \mathrm{C}$, with the maximum in February (mean temperature $26.7^{\circ}$ ) and minimum in July (mean temperature $21.0^{\circ}$ ).

\section{Taxonomy and floristic}

The present work was carried out between 2008 and 2010. Species identifications were made by consulting the specialized literature for the Orchidaceae family and through comparisons with specimens held in the following herbaria: HB, GUA, R, RB and RFA; herbarium acronyms follow Thiers (2013). Botanical material, collected during flowering or fruiting stages, was prepared according to usual techniques in taxonomy (Fidalgo \& Bononi 1989) and deposited in the Herbarium of the Universidade Federal do Rio de Janeiro (RFA).

\section{Data analysis}

\section{Cluster analysis}

The floristic composition of the study site was compared with surveys of the Orchidaceae family that had been carried out in seven other restinga areas in Rio de Janeiro state (Tab. 1). A binary matrix of presence/absence species was elaborated based on these lists. The names of the taxa were updated by specialists and taxa without precise identifications at the species level, as well as possible synonyms, were excluded from the analyses. Comparisons between the eight restinga areas were performed through Cluster Analysis, using the Sorensen similarity index and Ward's method (Minimum Variance Method). All analyses were run using PC-ORD version 5.0 for Windows software (McCune \& Mefford 2006).

\section{Ordination}

In order to identify the factors responsible for the observed clusterings of the restingas, Correspondence Factor Analysis (CFA) was performed. These analyses permitted the simul- 
Table 1. Restinga areas of Rio de Janeiro state, Brazil, with published inventories of their Orchidaceae floras that were used in cluster and ordination analyses.

\begin{tabular}{ll}
\hline Localities & Authors \\
\hline Ilha de Cabo Frio & De Mello (2003) \\
Jurubatiba & Alves \& Santana (2001) \\
Marambaia & Fraga et al. (2005) \\
Marapendi & Saddi et al. (2005) \\
Maricá & Araujo (2000) \\
Massambaba & Araujo (2000) \\
Praia do Sul & Araujo (2000) \\
\hline
\end{tabular}

taneous ordering of species and samples (Valentin 2012). The CFA was run on Statistica 7 software (Statsoft 2007).

\section{Results}

\section{Taxonomy and floristic}

We found 15 genera and 19 species belonging to the Orchidaceae family in Grumari restinga (Tab. 2). The genera Cattleya Lindl., Eltroplectris Raf., Epidendrum L., and Vanilla Mill had two species each, while the other genera were represented by only a single species.
Eight species were classified as new occurrences in the Grumari restinga (Alatiglossum ciliatum, Brassavola tuberculata, Campylocentrum micranthum, Cyclopogon variegatus, Malaxis cf. parthonii, Oeceoclades maculata, Sophronitis cernua, and Vanilla bahiana); another seven species had not been collected in over 20 years (Tab. 3).

Of the orchid species occurring in Grumari, $47 \%$ are endemic to Brazil and $21 \%$ are endemic to the Atlantic Forest (Tab. 2). Among the restinga of Rio de Janeiro, Epidendrum pseudodifforme is restricted to Grumari. In relation to the life-forms found, $47 \%$ of the species were terrestrial, $26 \%$ epiphytes, $11 \%$ epiphytic or terrestrial, $11 \%$ hemiepiphytes, and $5 \%$ were rupicolous (Tab. 2).

Thirty-two percent of the species present in the Grumari restinga were restricted to closed shrub formations (Alatiglossum ciliatum, Campylocentrum micranthum, Catasetum luridum, Cattleya guttata, Cyclopogon variegatus, and Epidendrum pseudodifforme), 5\% to open shrub formations (Cyrtopodium flavum), 5\% to the restinga forest formation (Malaxis cf. parthonii), while 32\% occurred in more than one formation type (Cattleya forbesii, Eltroplectris triloba, Habenaria leptoceras, Oeceoclades maculata, Vanilla bahiana, and Vanilla chamissonis); no location data was available for $26 \%$ of the species (Brassavola tuberculata, Sophronitis cernua, Eletroplectris calcarata, Epidendrum denticulatum, and Sacoila lanceolata).

Table 2. Life-forms, voucher information, and herbarium acronyms of the Orchidaceae species found in the Grumari restinga, Rio de Janeiro state, Brazil. (T) terrestrial, (R) rupicolous, (E) epiphytic, and (H) hemiepiphytic plants.

\begin{tabular}{|c|c|c|}
\hline Species & Life-form & Voucher specimen \\
\hline Alatiglossum ciliatum (Lindl.) Baptista a,b & $\mathrm{E}$ & M.M.Moreira et al. 28 (RFA) \\
\hline Brassavola tuberculata Hook. & $\mathrm{R}$ & D.Sucre et al. 3384 (RB) \\
\hline Campylocentrum micranthum (Lindl.) Rolfe & $\mathrm{E}$ & M.M.Moreira et al. 155(RFA) \\
\hline Catasetum luridum Lindl. ${ }^{a}$ & $\mathrm{E} / \mathrm{T}$ & M.M.Moreira et al. 102 (RFA) \\
\hline Cattleya forbesii Lindl. a,b & $\mathrm{E} / \mathrm{T}$ & M.M.Moreira et al. 38 (RFA) \\
\hline Cattleya guttata Lindl. a,b & $\mathrm{E}$ & D.S.D.Araujo et al. 5468 (GUA) \\
\hline Cyclopogon variegatus Barb. Rodr. & $\mathrm{T}$ & M.M.Moreira et al. 33 (RFA) \\
\hline Cyrtopodium flavum Link \& Otto ex Rchb.f. ${ }^{~}$ & $\mathrm{~T}$ & M.M.Moreira \& R.C.Lopes 65 (RFA) \\
\hline Eletroplectris calcarata (Sw.) Garay \& Sweet & $\mathrm{T}$ & D.S.D.Araujo et al. 5083 (GUA) \\
\hline Eltroplectris triloba (Lindl.) Pabst & $\mathrm{T}$ & M.M.Moreira et al. 133 (RFA) \\
\hline Epidendrum denticulatum Barb. Rodr. ${ }^{\text {a }}$ & $\mathrm{T}$ & N.Santos et al. $5152(\mathrm{R})$ \\
\hline Epidendrum pseudodifforme Hoehne \& Schltr. & $\mathrm{E}$ & D.S.D.Araujo et al. 5085 (GUA) \\
\hline Habenaria leptoceras Hook. ${ }^{a}$ & $\mathrm{~T}$ & M.M.Moreira et al. 113 (RFA) \\
\hline Malaxis cf. parthonii C. Morren & $\mathrm{T}$ & M.M. Moreira et al.112 (RFA) \\
\hline Oeceoclades maculata (Lindl.) Lindl. & $\mathrm{T}$ & M.M.Moreira et al. 4 (RFA) \\
\hline Sacoila lanceolata (Aubl.) Garay & $\mathrm{T}$ & L.Mauton 175 (RB) \\
\hline Sophronitis cernua Lindl. & $\mathrm{E}$ & M.Nadruz 385 (RB) \\
\hline Vanilla bahiana Hoehne ${ }^{\text {a }}$ & $\mathrm{H}$ & M.M.Moreira et al. 101 (RFA) \\
\hline Vanilla chamissonis Klotzsch & $\mathrm{H}$ & M.M.Moreira et al. 93 (RFA) \\
\hline
\end{tabular}

${ }^{\text {a }}$ Endemic to Brazil.

${ }^{\mathrm{b}}$ Endemic to Atlantic Forest. 
Table 3. Species not found in the Grumari restinga, Rio de Janeiro state, Brazil.

\begin{tabular}{lcc}
\hline Species & Last year recorded & Years without collections \\
\hline Brassavola tuberculata Hook. & 1968 & 42 \\
Cattleya guttata Lindl. & 1983 & 27 \\
Eltroplectris calcarata (Sw.) Garay \& Sweet & 1982 & 28 \\
Epidendrum denticulatum Barb. Rodr. & 1964 & 46 \\
Sacoila lanceolata (Aubl.) Garay & 1977 & 33 \\
Sophronitis cernua Lindl. & 1988 & 22 \\
\hline
\end{tabular}

Table 4. Species with restricted distributions in the restingas of Rio de Janeiro state, Brazil. Note that Marapendi restinga is not on the table, as this restinga has no restricted species.

\begin{tabular}{|c|c|}
\hline Restingas & Species \\
\hline \multirow{14}{*}{ Marambaia } & Anathallis aristulata (Lindl.) Luer \\
\hline & Aspidogyne kuczynskii (Porsch) Garay \\
\hline & Campylocentrum aciculatum (Rchb. f. \& Warm.) Cogn. \\
\hline & Catasetum hookeri Lindl. \\
\hline & Catasetum macrocarpum Rich. ex. Kunth \\
\hline & Christensonella subulata (Lindl.) Szlach. et al. \\
\hline & Encyclia patens Hook. \\
\hline & Epidendrum campaccii Hágsater \& L.Sanchez \\
\hline & Epidendrum strobiliferum Rchb. f. \\
\hline & Lophiaris pumila (Lindl.) Braem \\
\hline & Paradisanthus micranthus (Barb. Rodr.) Schltr. \\
\hline & Prosthechea fragrans (Sw.) W.E.Higgins \\
\hline & Psilochilus modestus Barb. Rodr. \\
\hline & Sarcoglottis fasciculata (Vell.) Schltr. \\
\hline \multirow{12}{*}{ Ilha de Cabo Frio } & Acianthera glanduligera (Lindl.) Luer \\
\hline & Brassavola flagellaris Barb. Rodr. \\
\hline & Campylocentrum organense (Rchb.f.) Rolfe \\
\hline & Cyclopogon bicolor (Ker-Gaw.) Schltr. \\
\hline & Epidendrum densiflorum Hook. \\
\hline & Epidendrum nocturnum Jacq. \\
\hline & Epidendrum paniculosum Barb. Rodr. \\
\hline & Epidendrum ramosum Jacq. \\
\hline & Epidendrum secundum Jacq. \\
\hline & Isochillus linearis (Jacq.) R. Br. \\
\hline & Polystachya foliosa (Lindl.) Rchb.f. \\
\hline & Pelexia novofriburgensis (Rchb.f.) Garay \\
\hline \multirow{5}{*}{ Praia do Sul } & Campylocentrum densiflorum Cogn. \\
\hline & Dryadella aviceps (Rchb.f.) Luer \\
\hline & Epidendrum fulgens Brongn. \\
\hline & Malaxis histionantha (Link) Garay \& Dunst. \\
\hline & Mormolyca rufescens (Lindl.) M.A.Blanco \\
\hline \multirow{2}{*}{ Grumari } & Epidendrum pseudodifforme Hoehne \& Schltr. \\
\hline & Sacoila lanceolata (Aubl.) Garay \\
\hline \multirow{2}{*}{ Maricá } & Acianthera saundersiana (Rchb. f.) Pridgeon \& M.W.Chase \\
\hline & Campylocentrum wawrae (Rchb. f. ex Beck) Rolfe \\
\hline \multirow{2}{*}{ Massambaba } & Campylocentrum sellowii (Rchb. f.) Rolfe \\
\hline & Vanilla planifolia Jacks. ex Andrews \\
\hline
\end{tabular}

\section{Data analysis}

A total of 72 Orchidaceae species composed the presence/absence matrix for the eight locations. The species Cattleya guttata and Cyrtopodium flavum showed the widest distributions, occurring in seven areas (the exception being the Marapendi restinga); no species occurred in all of the areas analyzed.

Of the remaining species, 37 were restricted to only one area of occurrence, with 14 occurring only in Marambaia, 12 only on Ilha de Cabo Frio, 5 only on Praia do Sul (Ilha Grande), and 2 species occurring only in the other sites (Grumari, Maricá, and Massambaba; Tab. 4).

The cluster analysis identified two major restinga groups. Group 1 was formed by two different areas Praia do Sul and Ilha de Cabo Frio, while Group 2 was comprised of Massambaba, Maricá, Grumari, Marapendi, Jurubatiba and Marambaia (Fig. 2). The Grumari and Maricá restingas showed the highest similarity (100\%), sharing ten species (Allatiglossum ciliatum, Campylocentrum micranthum, Cattleya forbesii, Cattleya guttata, Cyrtopodium flavum, Eltroplectris calcarata, Eltroplectris triloba, Epidentrum denticulatum, Vanilla bahiana, and Vanilla chamissonis) (Fig. 2). Jurubatiba and Marapendi had the second highest similarity, sharing six species (Cyrtopodim flavum, Eltroplectris calcarata, Epidendrum denticulatum, Oeceoclades maculata, Prescottia plantaginifolia, and Vanilla bahiana) (Fig. 2). Grumari, Maricá, Marapendi and Jurubatiba together formed a group with the third largest similarity index (Fig. 2). The correspondence factor analysis supports the cluster showing a group of restinga areas equal to the Group 2, and two sites as outliers: Praia do Sul and Ilha de Cabo Frio (Fig. 3)

\section{Discussion}

The present study aimed to assess orchid species diversity in the Grumari Restinga, Rio de Janeiro state, and compare, through cluster and ordination analyses, the orchid diversity among Grumari and other restinga areas located in Rio de Janeiro state.

We found 15 genera and 19 species of Orchidaceae in the Grumari restinga (eight new occurrences), in contrast to the 7 genera and 11 species recorded in a previous survey conducted in the same area by Argolo (2001). 


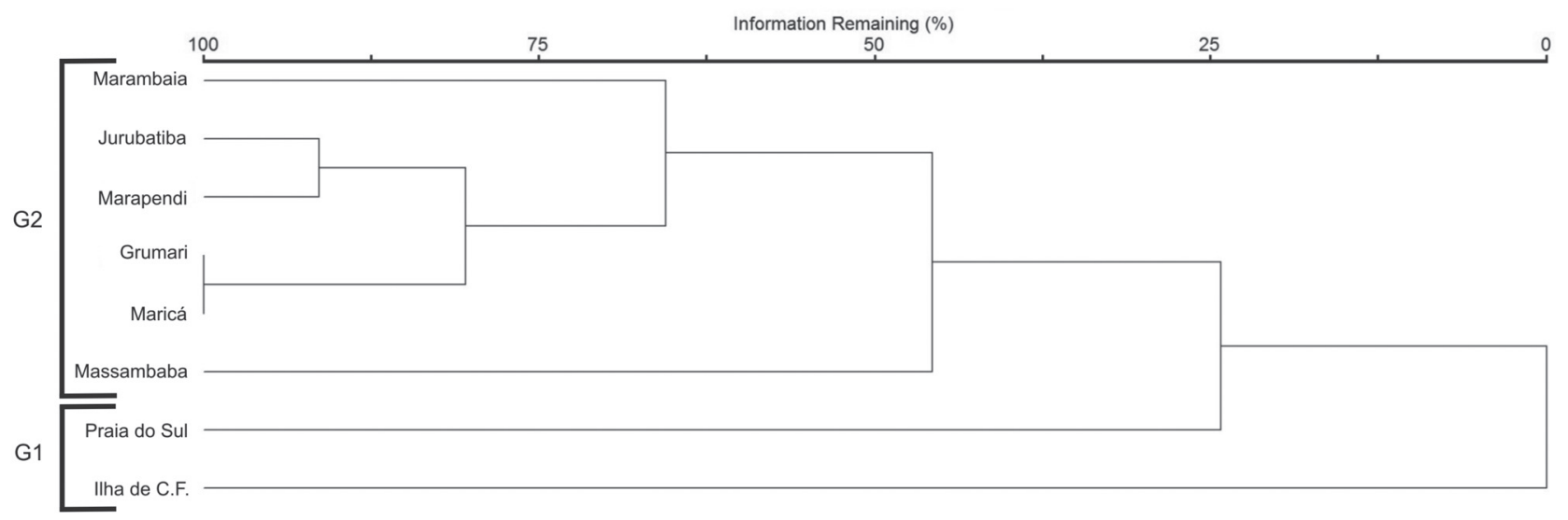

Figure 2. Dendrogram generated from the clustering method of Ward, using the Sorensen similarity index.

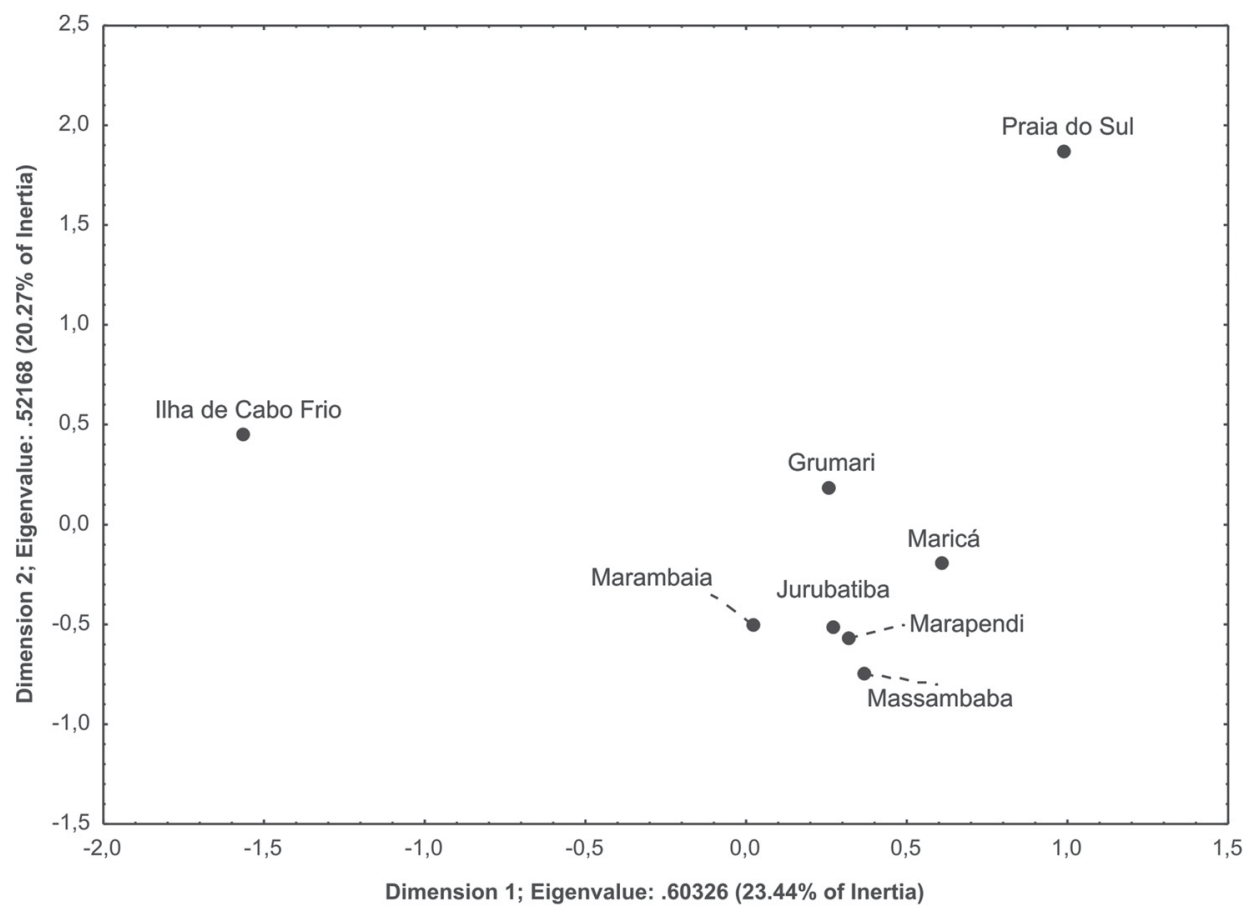

Figure 3. Correspondence factor analysis showing the ordination of the restinga sites in Rio de Janeiro state, Brazil.

Seven species that occurred in Grumari have not been collected in that area for over 20 years. It is worth noting that three of these species (Brassavola tuberculata, Cattleya guttata, and Sophronitis cernua) have a high ornamental value, which may explain the absence of these species. Another possible cause for the loss of these species was the construction of a road in the Grumari post-beach vegetation, which was occupied by Epidendrum denticulatum and Sacoila lanceolata.

About $47 \%$ of the orchid species found in Grumari had terrestrial life forms. Similar high rates of terrestrial individuals were also observed in other restinga sites, as described by Araujo (2000) for the restingas of Rio de Ja- neiro state and by Fraga \& Peixoto (2004) for the restingas in Espírito Santo state. This appears to be a characteristic of this family in this ecosystem - even though most orchid species in Atlantic Forests have epiphytic life forms.

Both cluster and ordination analyses demonstrated that the restingas located on islands (Ilha de Cabo Frio and Praia do Sul in Ilha Grande) are different from those situated on the mainland. Many species of plants and animals that occur on islands are different from those found in similar nearby mainland sites, as geographic isolation often provides more favorable conditions for species differentiation, resulting in low similarity indices between those areas. 
The restingas that demonstrated the highest similarity (Grumari and Maricá) were not located very close to each other, in a way that other environmental factors, such as temperature, precipitation, and proximity to the Atlantic Forest, may be involved in the establishment and distribution of their orchid species. Earlier studies found no correlations between similarity and geographical distances for the Orchidaceae in others areas of Brazil (De Abreu et al. 2011). As such, we suggest that future studies should assess the influence of environmental variables such as temperature, precipitation, as well as the proximity to Atlantic Forest areas to determine what factors are most important in determining the distribution of this family in the restingas.

\section{Acknowledgments}

The authors would like to thank the Universidade Federal do Rio de Janeiro (UFRJ) and the Fundação de Amparo à Pesquisa do Estado do Rio de Janeiro (FAPERJ) for their financial support. The authors are also very thankful to Jean Louis Valentin for assisting with the data analysis.

\section{References}

Alves, R.J.V. \& Santana, I.C. 2001. Orchidaceae. Pp. 109. In: Costa, A.F. \& Dias, I.C.A. (eds.). Flora do Parque Nacional da Restinga de Jurubatiba e arredores, Rio de Janeiro, Brasil: listagem, florística e fitogeografia. Rio de Janeiro, Museu Nacional.

Araujo, D.S.D. 2000. Análise Florística e fitogeográfica das Restingas do Estado do Rio de Janeiro. Tese de doutorado. Rio de Janeiro, Universidade Federal do Rio de Janeiro.

Argolo, A.M. 2001. Levantamento florístico, caracterização fisionômica e comparação da restinga de Grumari, RJ, com outras restingas do Estado do Rio de Janeiro. Dissertação de Mestrado. Rio de Janeiro, Universidade Federal do Rio de Janeiro, Museu Nacional.

Azevedo, C.O. \& Van Den Berg, C. 2007. A família Orchidaceae no Parque Municipal de Mucugê, Bahia, Brasil. Hoehnea 34(1): 1-47.

Barros, F.; Vinhos, F.; Rodrigues, V.T.; Barberena, F.F.V.A.; Fraga, C.N.; Pessoa, E.M. 2013. Orchidaceae in Lista de Espécies da Flora do Brasil.
Jardim Botânico do Rio de Janeiro. Disponível em http://floradobrasil. jbrj.gov.br/jabot/floradobrasil/FB179. Consulted on April 3, 2013.

Chase, M.W.; Cameron, K.M.; Barrett, R.L. \& Freudenstein, J.V. 2003. DNA data and Orchidaceae systematics: a new phylogenetic classification. Pp.69-89. In: Dixon, K.W.; Kell, S.P.; Barrett, R.L. \& Cribb, P.J. (eds.). Orchid Conservation. Natural History Publications, Kota Kinabalu, Sabah.

Cunha, M.F.B. \& Forzza, R.C. 2007. Orchidaceae no Parque Natural Municipal da Prainha, RJ, Brasil. Acta Botanica Brasilica 21 (2): 383-400.

De Abreu, N.L.; Menini Neto, L. \& Konno, T.U.P. 2011. Orchidaceae das Serras Negra e do Funil, Rio Preto, Minas Gerais, e similaridade florística entre formações campestres e florestais do Brasil. Acta Botanica Brasilica 25(1): 58-57.

De Mello, A.C.G. 2003. Orchidaceae da Ilha de Cabo Frio, Município de Arraial do Cabo, RJ. Dissertação de Mestrado. Rio de Janeiro, Universidade Federal do Rio de Janeiro, Museu Nacional.

Dressler, R.L. 1981. The Orchids: Natural history and classification. Cambridge: Harvard University.

Fidalgo, O. \& Bononi, V.L.R. 1989. Técnicas de coleta, preservação e herborização de material botânico. São Paulo: Instituto de Botânica.

Fraga, C.N. \& Peixoto, A.L. 2004. Florística e ecologia das Orchidaceae das restingas do estado do Espírito Santo. Rodriguésia 55(84): 5-20.

Fraga, C.N.; Kollmann, L.J.C. \& Menezes, L.F.T. 2005. Orchidaceae da Marambaia. Pp. 121. In: Menezes, L.F.T.; Peixoto, A.L. \& Araujo, D.S.D. (Eds). História Natural da Marambaia. Rio de Janeiro, Seropédica. EDUR.

McCune B. \& Mefford, MJ. 2006. PC-ORD v5. Multivariate Analysis of Ecological Data. Gleneden Beach, OR, USA. MJM Software Design.

Miller, D. \& Warren, R. 1996. Orquídeas do Alto da Serra: da Mata Atlântica Pluvial do Sudeste do Brasil. Rio de Janeiro, Lis Gráfica Ltda.

Myers, N.; Mittermeier, R.A.; Mittermeier, C.G.; Fonseca, G.A. \& Kent, J. 2000. Biodiversity hotspots for conservation priorities. Nature 403(24): 853-858

Rocha, C.F.D.; Bergallo, H.G.; Van Sluys, M.; Alves, M.A.S. \& Jamel, C.E. 2007. The remnants of restinga habitats in the Brazilian Atlantic Forest of Rio de Janeiro State, Brazil: habitat loss and risk of disappearance. Brazilian Journal of Biology 67(2): 263-273.

Saddi, E.M.; Lopes, R.C. \& Andreata, R.H.P. 2005. Floristic and conservation of Orchidaceae at Rio das Pedras Reserve. Selbyana 26(1,2):318-325.

Thiers, B. 2013. Index Herbariorum: A global directory of public herbaria and associated staff. New York Botanical Garden's Virtual Herbarium. Available at: http://sweetgum.nybg.org/ih/. Consulted on April 19, 2013.

Valentin, J.L. 2012. Ecologia Numérica: uma introdução à análise multivariada de dados ecológicos. Rio de Janeiro, Interciência.

StatSoft, Inc.. Statistica (data analysis software system), version 7.1. 2005. $<$ www.statsoft.com $>$ 